\title{
A CHANGE IN EDITORSHIP OF THE JOURNAL
}

Dr. Henry L. Plaine has recently resigned as editor-in-chief of The Ohio Journal of Science after having served in this capacity for the past six years. His services during these past years are greatly appreciated.

The new editor-in-chief is Dr. David H. Stansbery of The Ohio State Museum and the Department of Zoology and Entomology of The Ohio State University. Dr. Stansbery has served as associate editor on the Journal staff during the past year.

The editorial policy of the Journal will, in general, follow that established by previous editors. Papers, notes, and symposia in all fields of science will be considered for publication. Details of form and style will in most instances conform to those set by the Style Manual for Biological Journals, compiled by the Conference of Biological Editors, American Institute of Biological Sciences. 